\title{
Improvement of the efficacy of dihydroartemisinin with atorvastatin in an experimental cerebral malaria murine model
}

Jérôme Dormoi ${ }^{1,2}$, Sébastien Briolant ${ }^{1,2,3,4}$, Aurélie Pascual ${ }^{1,2}$, Camille Desgrouas $^{5}$, Christelle Travaillé ${ }^{5}$ and Bruno Pradines ${ }^{1,2^{*}}$

\begin{abstract}
Background: The medical care of malaria is a clinical emergency because it may develop into severe malaria, which has a high risk of complications and death. One of the major complications of Plasmodium falciparum infections is cerebral malaria (CM), which is responsible for at least 175,000 deaths worldwide each year and has long-term neurological sequelae. Moreover, treatment for CM is only partially effective. Statins are now known to have anti-inflammatory action, to attenuate sepsis and to have neuroprotective effects. In vitro, atorvastatin (AVA) has an anti-malarial activity and has improved the activity of quinine (QN), mefloquine (MQ), and dihydroartemisinin (DHA).
\end{abstract}

Objectives: This study had two objectives. First, the ability of AVA to enhance DHA efficacy by improving the survival rate for $\mathrm{CM}$ and also decreasing signs of CM was evaluated in a murine model of experimental cerebral malaria (ECM), which was designed in C57BL6/N mice. Second, the inflammatory biomarkers were assessed at D6 and D10 in mice treated by DHA and in untreated mice in which clinical signs of CM appear rapidly and death occurs before D12. Both experiments were designed with seven days of treatment with $40 \mathrm{mg} / \mathrm{kg}$ AVA combined with five days of $3 \mathrm{mg} / \mathrm{kg}$ DHA administered intraperitoneally.

Results: AVA in combination with DHA in a therapeutic scheme leads to a significant delay in mouse death, and it has an effect on the onset of CM symptoms and on the level of parasitaemia. Evaluation of the biomarkers highlights the significant difference between treated and control mice for five cytokines and chemokines (Eotaxin-CCL11, IL-13, LIX-CXCL5, MIP1b-CCL4 and MIP2) that are known to have a role in chemotaxis.

Conclusions: The combination of DHA and AVA seems to be effective as a therapeutic scheme for improving mouse survival but less effective for cytokine modulation, which is associated with protection against CM. These results call for clinical trials of AVA as an adjuvant with anti-malarial therapy, especially with artemisinin-based combination therapy, in CM treatment or prevention.

Keywords: Malaria, Plasmodium berghei, Antimalarial, Resistance, In vivo, Artemisinin, Statin

\footnotetext{
* Correspondence: bruno.pradines@free.fr

'Unité de Parasitologie, Département d'Infectiologie de Terrain, Institut de Recherche Biomédicale des Armées, Marseille, France

${ }^{2}$ Unité de Recherche sur les Maladies Infectieuses et Tropicales Emergentes, UM 63, CNRS 7278, IRD 198, Inserm 1095, Aix Marseille Université, Marseille, France

Full list of author information is available at the end of the article
}

\section{Biomed Central}

(c) 2013 Dormoi et al.; licensee BioMed Central Ltd. This is an Open Access article distributed under the terms of the Creative Commons Attribution License (http://creativecommons.org/licenses/by/2.0), which permits unrestricted use, distribution, and reproduction in any medium, provided the original work is properly cited. 


\section{Background}

In 2002, the World Health Organization (WHO) recommended that artemisinin-based combination therapy (ACT) be used for all cases of uncomplicated malaria. Four years later, the WHO added the recommendation that artesunate be deployed as the first-line treatment for severe malaria in adults and that it replace quinine because of its higher efficacy and better tolerance [1]. In 2010, a large-scale trial confirmed the effectiveness of artesunate in the treatment of severe malaria in children [2]. In 2011, the WHO recommended artesunate as the first-line treatment for severe malaria. In recent years, several studies have reported clinical failures, or at least extended parasite clearance times, in Cambodia [3-5]. In 2010, quinine remained widely used, especially in Africa, for severe malaria [6], and a number of studies have since been carried out to increase the effectiveness of quinine, seeking drug interactions that enhance anti-malarial effect $[7,8]$.

A great scientific effort is aimed at elucidating the mechanisms underlying the resistance to anti-malarial drugs, with the hope of restoring and improving the efficacy of existing drugs and developing new drugs that can bypass the resistance mechanisms. One of the strategies that has been used to reduce the prevalence of malaria is the use of drug combinations. Using a combination of drugs prevents resistance to each drug from developing and thus reduces the overall transmission rate of malaria [9]. There is an urgent need for the discovery of suitable drug combinations with artemisinin derivatives.

Statins, inhibitors of 3-hydroxy-3-methylglutaryl-Coenzyme A reductase (HMG-CoA reductase), are a family of lipid-lowering drugs that have recently been demonstrated to have in vitro anti-malarial properties [10,11]. Moreover, atorvastatin (AVA) improved the in vitro activity of mefloquine (MQ) [12], quinine (QN) [13] or dihydroartemisinin (DHA) [14] at plasma concentrations expected in clinical observations for patients taking $80 \mathrm{mg}$ of AVA daily ( 0.1 to $0.5 \mu \mathrm{M})$ [15]. Nevertheless, AVA, used alone, failed to prevent death from cerebral malaria (CM) or to affect the parasitaemia of infected mice [16]. AVA combined with MQ led to a significant delay in mouse death and affected on the onset of CM symptoms [17].

The objective of the present work was to evaluate the in vivo efficacy of AVA with DHA or QN, the two antimalarial drugs recommended for severe malaria that have in vitro synergy when combined with AVA, in a murine model of experimental cerebral malaria (ECM). The doses of DHA or QN used in the present study were relevant with clinical and with plasma concentrations expected in clinical observations for patients. Animal models do not exactly reproduce human malaria, but they nevertheless exhibit some similarities to human $\mathrm{CM}$, and the use of the
Plasmodium berghei ANKA rodent parasite model is generally accepted as one of the valid models for studying ECM pathogenesis $[18,19]$.

\section{Methods \\ Mice}

All animals were pathogen free and were housed under standard conditions, with unlimited access to food and water. All efforts were made to minimize animal suffering. All experiments adhered to French guidelines for animal research and were approved by the ethics committee of the Institut de Recherche Biomédicale des Armées-Antenne de Marseille (Number 2007-08).

\section{Experimental cerebral malaria and biomarker levels analysis}

Ninety (for experimental cerebral malaria) and sixty (for biomarker levels analysis) female C57Bl6/N mice, 6-7 weeks old and weighting 18-22 g (Charles Rivers, France), were infected on day 0 (D0) with P. berghei ANKA by intraperitoneal (i.p.) inoculation of $10^{5}$ parasitized erythrocytes in $200 \mu \mathrm{L}$ from infected donor C57Bl6/N mice, diluted in normal saline solution.

\section{Drug and therapy protocol}

AVA calcium salt was purchased from Molekula (UK), and QN and DHA were obtained from Sigma (St Louis, MO, USA). QN and DHA were dissolved in normal saline solution. AVA was dissolved in dimethyl sulfoxide (DMSO) $1 \%(\mathrm{v} / \mathrm{v})$ in $\mathrm{NaCl} 0.9 \%$ at 20 or $40 \mathrm{mg} / \mathrm{kg}$. The AVA solutions were sonicated (Bioblock Scientific/Ultrasonic Processors-VCX $600 \mathrm{~W})$ for 5 minutes on ice $\left(4^{\circ} \mathrm{C}\right)$ at $75 \%$ amplitude with 5 seconds on pulse and 10 seconds on pause.

\section{Dihydroartemisinin-atorvastatin combination}

When parasitaemia was about $0.5 \%$, the mice were treated by i.p. injection with $3 \mathrm{mg} / \mathrm{kg}$ DHA alone for 5 days, $40 \mathrm{mg} / \mathrm{kg}$ AVA alone for 7 days or the combination, $3 \mathrm{mg} /$ $\mathrm{kg}$ DHA (5 days) and $40 \mathrm{mg} / \mathrm{kg}$ AVA (7 days). Control mice were treated with $\mathrm{NaCl} 0.9 \%$ only.

\section{Quinine-atorvastatin combination}

When parasitaemia was about $0.5 \%$, the mice were treated by i.p. injection with $40 \mathrm{mg} / \mathrm{kg}$ QN alone for 7 days, $40 \mathrm{mg} / \mathrm{kg}$ AVA alone for 7 days or $40 \mathrm{mg} / \mathrm{kg}$ QN combined with $40 \mathrm{mg} / \mathrm{kg}$ AVA (high dose) or $20 \mathrm{mg} / \mathrm{kg}$ AVA (low dose) for 7 days. Control mice were treated with $\mathrm{NaCl} 0.9 \%$ only.

\section{Parasitemia and clinical parameters}

Parasitemia was determined daily using Giemsa-stained thin blood smears collected from the tail vein, by assessing the number of infected red blood cells based on 3,000 
erythrocytes if $>1 \%$ were infected and based on 10,000 erythrocytes if $<1 \%$ were infected (1.9 to $2.9 \%$ ). The animals were under daily supervision for clinical signs, neurological symptoms and weight. ECM was diagnosed by clinical signs based on a simplified SHIRPA protocol [20] with at least two symptoms in at least two of the three different groups: 1) alteration of autonomous function (piloerection, defecation, urination, respiration rate); 2) alteration of muscle tone and strength (grip strength, body tone, limb tone, abdominal tone); and 3) ataxia, paralysis (mono-, hemi-, para-, or tetraplegia), deviation of the head, convulsions and coma.

\section{Multiplexed microsphere cytokine immunoassay}

Serum $(50 \mu \mathrm{L})$ from the control $(\mathrm{CT})$, AVA, DHA and DHA combined with AVA (DHA + AVA) groups was evaluated for 32 circulating cytokines simultaneously (Eotaxin, G-CSF, GM-CSF, IFN $\gamma$, IL-1 $\alpha$, IL-1 $\beta$, IL-10, IL-12(p40), IL-12(p70), IL-13, IL-15, IL-17, IL-2, IL-3, IL-4, IL-5, IL-6, IL-7, IL-9, IP-10, KC, LIF, LIX-CXCL5, MCP-1, M-CSF, MIG, MIP1-CCL3, MIP1ß-CCL4, MIP-2, RANTES, TNF, and VEGF) using a multiplex bead-based cytokine immunoassay coupled with the Luminex ${ }^{200}$ system (Biorad) and mouse-specific bead sets from the MILLIPLEX ${ }^{\text {mo }}$ MAP mouse cytokine/chemokine kit 32 Wells Plate Assay (MCYTMAG-70 K-PX32-Millipore, Belford, MA, USA), according to the manufacturer's instructions. The results were interpolated using a fiveparameter logistic method. Samples were tested at a 1:1 dilution.

\section{Statistical analyses}

All statistical analyses were performed with $\mathrm{R}$ software (version 2.10.1). Survival analyses were performed by Kaplan-Meier log rank test. Box plot graphs outlined the 25th and 75th percentiles and the median, with bars representing the minimum and maximum. Box plot graphs were made with GraphPad Prism 5 software (version 5.01), and P-values $<0.05$ indicate a significant difference.

\section{Results}

\section{Effects of the dihydroartemisinin/atorvastatin combination on mortality in ECM}

For the curative treatment, there was a significant difference $(P=0.0029)$ in survival between untreated mice and mice treated with a $3 \mathrm{mg} / \mathrm{kg}$ dose of DHA or the combination of DHA with $40 \mathrm{mg} / \mathrm{kg}$ AVA. In the CT group, all mice died before D10 with specific signs of CM and with parasitaemia $<10 \%$ (5.2 to $10 \%$ ) (Figure 1). In the AVA group, more than half of the mice died before D5 with specific signs of CM and with parasitaemia $<10 \%$ (4.8 to $8.8 \%$ ). The last four mice died at D10, D21, D22, and D23 with $19 \%, 85 \%, 74 \%$ and $67 \%$ parasitaemia, respectively. AVA alone is ineffective against $P$. berghei, and there was no significant difference between the CT and AVA groups $(\mathrm{P}=0.283)$. The mice treated with $3 \mathrm{mg} / \mathrm{kg}$ DHA died between D2 and D27 (parasitaemia from 1.3 to $84 \%$ ). During the 5 days of treatment, parasitaemia remained low ( $0.4 \%$ on D3); however, after these 5 days of treatment, parasitaemia increased to $1.9 \%$. There was no death before D10 in the group of mice treated with $3 \mathrm{mg} / \mathrm{kg}$ DHA combined with $40 \mathrm{mg} / \mathrm{kg}$ AVA. After 5 days of treatment with $3 \mathrm{mg} / \mathrm{kg}$ DHA combined with 7 days of treatment with $40 \mathrm{mg} / \mathrm{kg}$ AVA, parasitaemia decreased to $0.4 \%$ before it started to increase (Figure 2). The remaining mice died between D15 and D26, with parasitaemia that ranged from 11 to $84 \%$.

Treatments with DHA and the combination of AVA and DHA were significantly effective for CM treatment $(\mathrm{P} \leq 0.05$ and $\mathrm{P} \leq 0.005$, respectively). However, for mice treated with DHA alone, half of the mice died not only with $80 \%$ of the specific signs of CM but also with parasitaemia that ranged between $3.5 \%$ and $7 \%$ from D2 to D11. After D11, the mice died from anaemia with parasitaemia that ranged from $39.8 \%$ to $91 \%$, and by D23, all the mice were dead. The combination of DHA and AVA was more effective than DHA alone in the murine model of ECM $(\mathrm{P}<0.05)$ for the first two weeks $(\mathrm{D} 15)$ after the appearance of $P$. berghei in red blood cells. The analyses showed that, after these two weeks, the effects of this combination were not significant $(P=0.6)$. It seems that the efficacy of the combination is due to synergy between the two compounds, as there was a significant difference between the efficacy of DHA alone and that of the combination of AVA and DHA ( $\mathrm{P}=0.028)$.

\section{Effects of the quinine/atorvastatin combination on mortality in ECM}

In the curative treatment, there was a significant difference $(\mathrm{P}=1.1 \mathrm{e}-8)$ in survival between untreated mice and mice treated with a $40 \mathrm{mg} / \mathrm{kg}$ dose of $\mathrm{QN}$ or the combination of QN with $40 \mathrm{mg} / \mathrm{kg}$ AVA or $20 \mathrm{mg} / \mathrm{kg}$ AVA. In the control group, all of the mice died at D7 with specific signs of $\mathrm{CM}$ and parasitaemia that ranged from $16.5 \%$ to $46.7 \%$ $($ mean $=40.6 \%)$ (Figure 3$)$. The mice treated with the $40 \mathrm{mg} / \mathrm{kg}$ dose of QN died between D12 and D22. After 7 days of treatment with the $40 \mathrm{mg} / \mathrm{kg}$ dose of QN, parasitaemia increased to between $18 \%$ and $52 \%$ (mean $=40 \%)$ at D12, at which point the mice died without specific signs of CM but with the same level of parasitaemia as that of the control group. Meanwhile, one mouse $(25 \%)$ died at D13 and one mouse died at D22, with 28.8 and $91 \%$ parasitaemia, respectively.

In the group of mice treated with $40 \mathrm{mg} / \mathrm{kg}$ QN combined with $40 \mathrm{mg} / \mathrm{kg}$ AVA, mice did not survive longer and died from cerebral malaria at D12, with parasitaemia that ranged from $26.6 \%$ to $42.7 \%$. In all, $75 \%$ of mice treated with $40 \mathrm{mg} / \mathrm{kg}$ QN combined with $20 \mathrm{mg} / \mathrm{kg}$ 


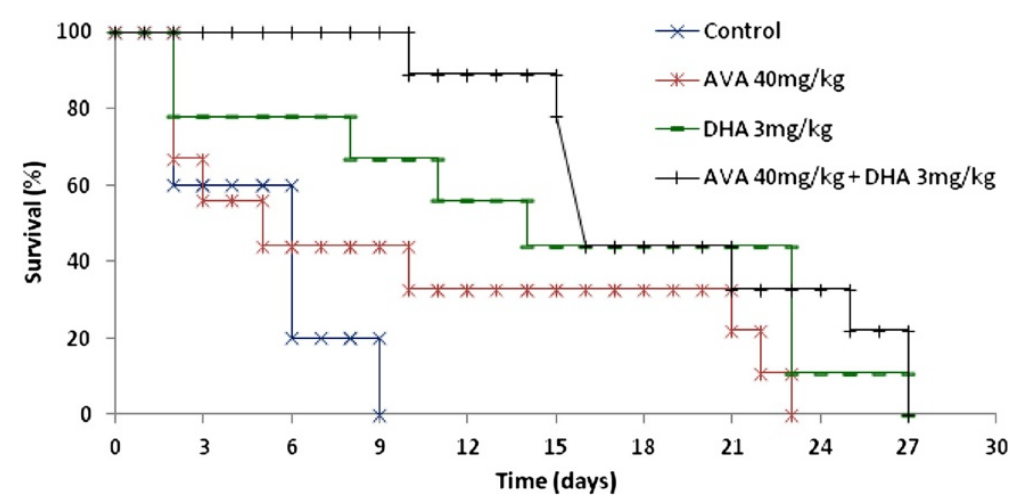

Figure 1 Survival curve of C57BL6/N mice infected on day 0 (D0) with P. berghei ANKA parasites and treated with $3 \mathrm{mg} / \mathrm{kg}$ dihydroartemisinin (five days), $40 \mathrm{mg} / \mathrm{kg}$ atorvastatin (seven days) or $3 \mathrm{mg} / \mathrm{kg}$ dihydroartemisinin combined with $40 \mathrm{mg} / \mathrm{kg}$ atorvastatin for five and seven days, respectively.

AVA died at D12, with parasitaemia that ranged from 30.2 to $55.9 \%$ (mean $=39.8 \%)$ but also without specific signs of CM. The remaining $25 \%$ of the mice died at D15 and D23, with $32.3 \%$ and $98 \%$ parasitaemia, respectively (Figure 4). Meanwhile, there was no significant difference between the two doses of AVA used in combination with quinine $(\mathrm{P}=0.202)$.

\section{Biomarker levels in the different mice groups}

The parasitaemia levels were similar in the CT, AVA, DHA and DHA + AVA groups at D6 (0.1 to 0.5\%). To analyse the biomarker concentration, five mice in each group were euthanized, and sera were collected at D6 and D10. Only five cytokines and chemokines were identified from the analysis, with $\mathrm{P}<0.05$ (Figure 5).

At day 6, some biomarkers had variations; for example, eotaxin/CCL11 had a significant increase in the DHA group versus the $\mathrm{CT}$ group $(\mathrm{P}=7.9 \mathrm{e}-3)$, but in the DHA + AVA group, it had a significantly lower concentration $(\mathrm{P}=1.59 \mathrm{e}-2)$ compared to the CT group. Additionally, the concentration of IL-23 was significantly lower in the DHA + AVA group when compared to the CT group $(\mathrm{P}=1.59 \mathrm{e}-2)$. In contrast to Eotaxin/CCL11, MIP2 was down-regulated in the DHA group $(\mathrm{P}=5.71 \mathrm{e}-2)$ but was up-regulated in the DHA + AVA group.

At day 10, three biomarkers were detected with the only significant difference being between the CT and DHA + AVA groups. Eotaxin/CCL11 and LIX-CXCL5 were found to be highly regulated with $\mathrm{P}=7.9 \mathrm{e}-3$ and $\mathrm{P}=1.59 \mathrm{e}-2$, respectively, although MIP1 $\beta$-CCL4 had a lower concentration in the DHA + AVA group $(\mathrm{P}=7.9 \mathrm{e}-3)$.

\section{Discussion}

The present results demonstrate that, in an in vivo ECM model, AVA improved the therapeutic effects of DHA but not those of $\mathrm{QN}$. In a therapeutic i.p scheme, the combination of AVA and DHA versus DHA alone resulted in a significant delay in mouse death and had an effect on the onset of CM symptoms and on the level of parasitaemia. The experimental conditions did not prevent death,

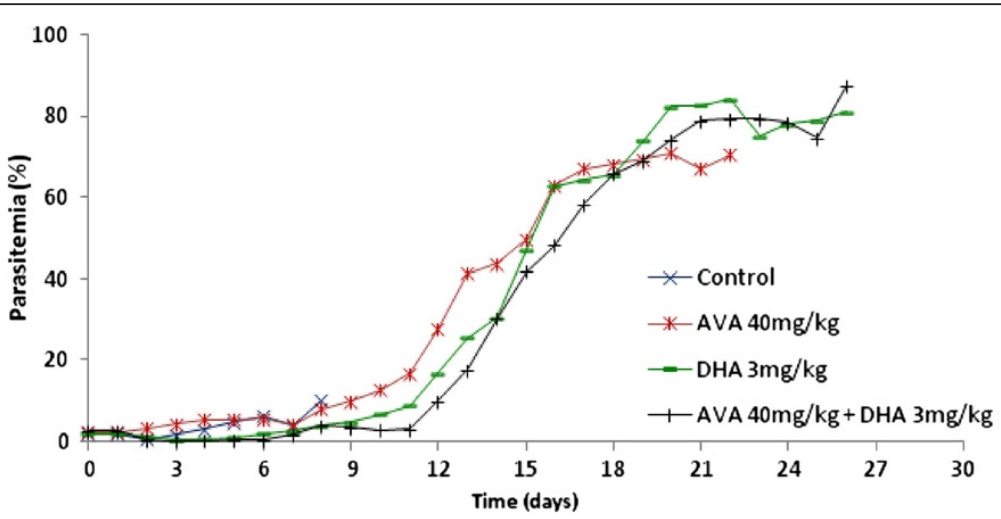

Figure 2 Parasitemia in dihydroartemisinin and atorvastatin assay for the control group, $3 \mathrm{mg} / \mathrm{kg}$ dihydroartemisinin (five days), $40 \mathrm{mg} / \mathrm{kg}$ atorvastatin (seven days) or $3 \mathrm{mg} / \mathrm{kg}$ dihydroartemisinin combined with $40 \mathrm{mg} / \mathrm{kg}$ atorvastatin for five and seven days, respectively. 


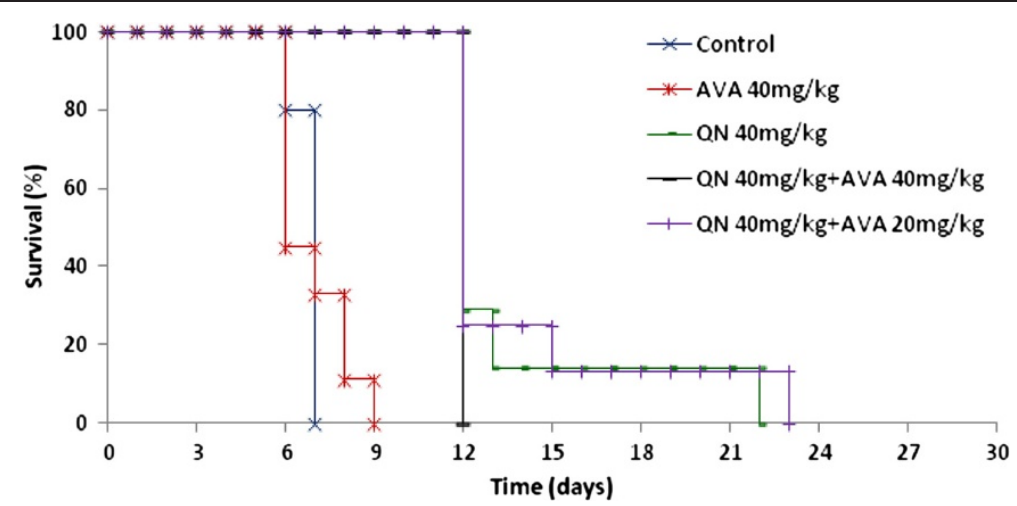

Figure 3 Survival curve of C57BL6/N mice infected on day 0 (D0) with $P$. berghei ANKA parasites and treated with $40 \mathrm{mg} / \mathrm{kg}$ quinine (five days), $40 \mathrm{mg} / \mathrm{kg}$ atorvastatin (seven days) or $40 \mathrm{mg} / \mathrm{kg}$ quinine combined with $40 \mathrm{mg} / \mathrm{kg}$ atorvastatin for five and seven days, respectively.

but it seemed that the mice of the combination group did not die of CM, as the mice in the other groups did, but rather died of anaemia with high parasitaemia. As shown previously, AVA, like other statins, is not effective alone as a treatment for severe malaria [21,22]. Even if AVA improved the in vitro activity of DHA [14], QN [13] or MQ [12], AVA acts differently in an in vivo combination with these three anti-malarial drugs. AVA significantly delays mouse death by $\mathrm{CM}$ and inhibits the development of $\mathrm{CM}$ symptoms when combined with anti-malarial drugs that, alone, had little or no effect in our ECM model, such as DHA (50\% of the mice died with specific $\mathrm{CM}$ symptoms) or MQ, as previously described [17]. AVA does not improve the efficacy of anti-malarial drugs that have a significant effect when used alone, such as QN (no death with specific symptoms of $\mathrm{CM}$ ). The pathogenesis of $\mathrm{CM}$ in the murine model relies solely on the inflammatory response, unlike the pathogenesis of human CM. Indeed, the cytoadherence phenomenon does not exist in P. berghei mouse infections [20,23,24]. AVA showed the ability to strongly protect endothelial cells against
P. falciparum-induced collateral damage, such as cell apoptosis and endothelial barrier permeabilization [23,24]. Additionally, AVA can be used to reduce the cytoadherence of $P$. falciparum on endothelial cells, a key event during infection, along with the inflammatory burst, which is involved in the pathogenesis of severe human malaria cases. Moreover, lovastatin decreases neuroinflammation and prevents cognitive impairment after cerebral malaria in mice infected with $P$. berghei ANKA [25].

Obviously, experimental models cannot reproduce all the features of human diseases. Among the differences between experimental models and the human disease are that leucocytes, rather than parasitized red blood cells, are the main cells sequestered in brain vessels; parasitized red blood cells lack knobs; and infected mice do not develop high fever [18]. However, the model based on C57BL6 mice infected by $P$. berghei ANKA shares the main features observed in human CM, with a clinical picture that includes coma, neurological impairment and a systemic, as well as a local, immune response $[20,26-28]$. In the present study, as is usually described,

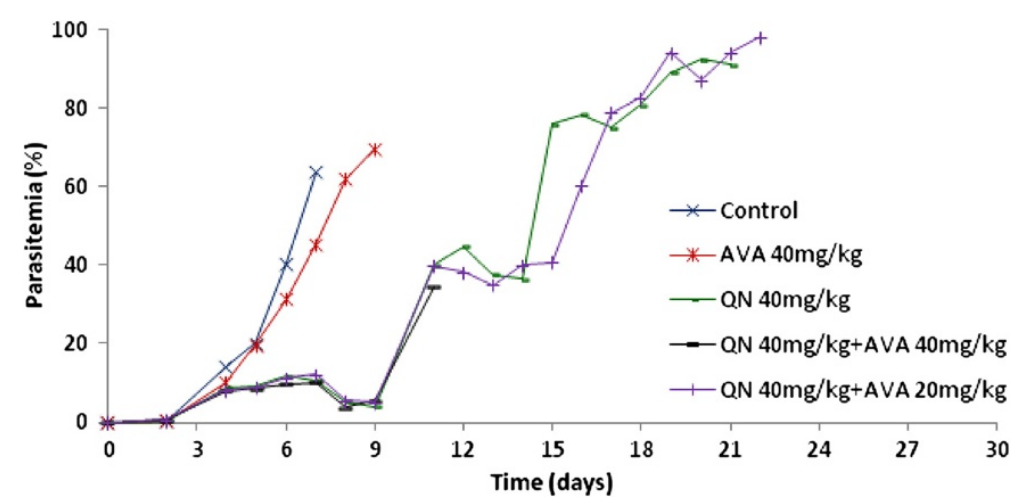

Figure 4 Parasitemia in dihydroartemisinin and atorvastatin assay for the control group, $40 \mathrm{mg} / \mathrm{kg}$ quinine (five days), $40 \mathrm{mg} / \mathrm{kg}$ atorvastatin (seven days) or $40 \mathrm{mg}$ quinine combined with $40 \mathrm{mg} / \mathrm{kg}$ atorvastatin for five and seven days, respectively. 


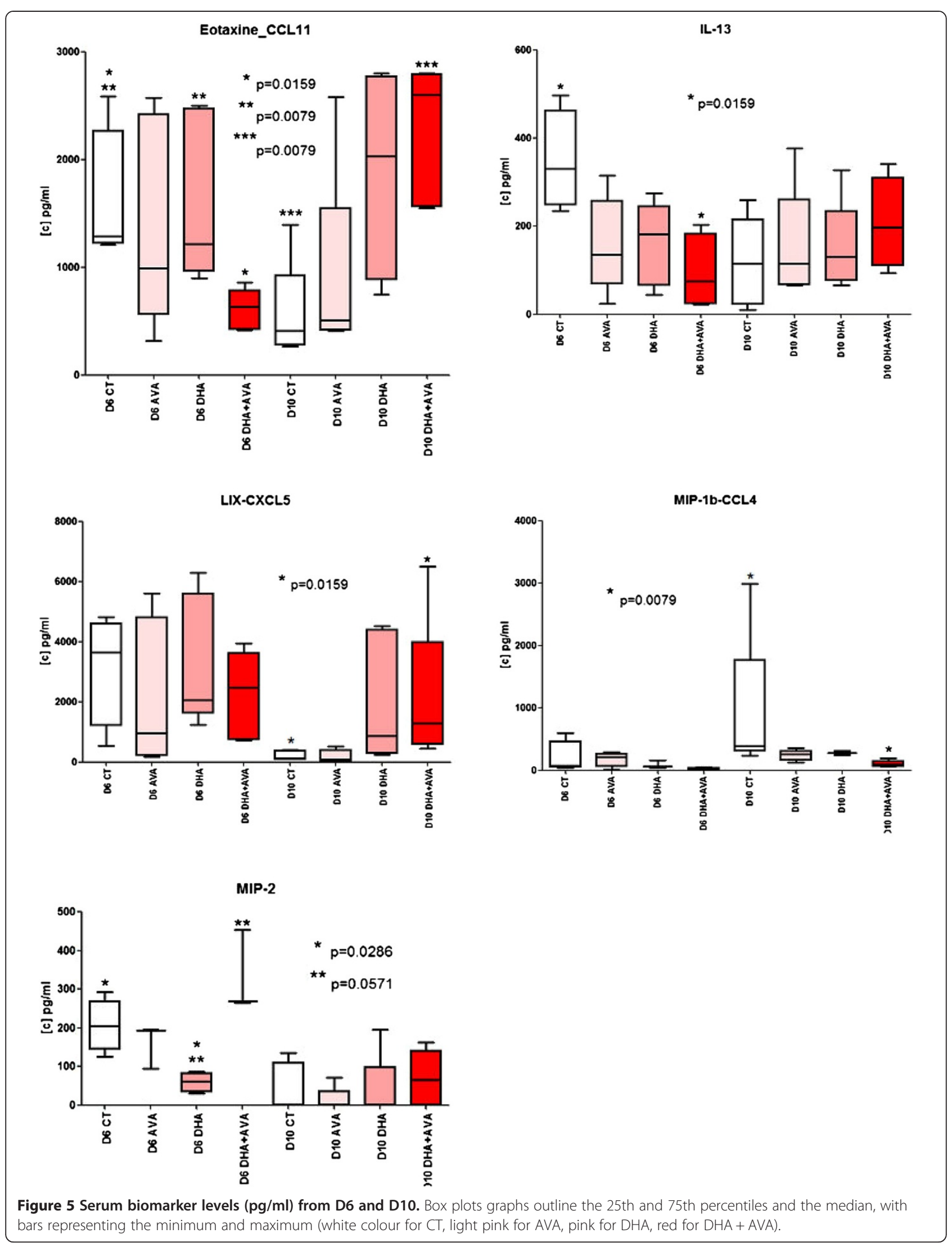


death occurred after $8-12$ days for 85 to $95 \%$ of the mice. Different host-parasite factors such as genetic background, age, amount of inocula, course of parasitaemia and clonal variation of the parasite may also interfere with the incidence of $\mathrm{CM}$ and may explain the different evolutions of parasitaemia in the present experiments [26].

The difference between the DHA + AVA group and the DHA alone group could be explained by the modulation of the inflammatory response by AVA. This modulation may prevent the cytoadherence at concentrations higher than $0.5 \mu \mathrm{M}$ of AVA and endothelial damage related to $\mathrm{CM}$ or it may inhibit diapedesis, due to its pleiotropic effects [29-31]. A dose of $0.5 \mu \mathrm{M}$ is relevant with plasma concentrations expected in clinical observations for patients taking $80 \mathrm{mg}$ of AVA daily [15]. The present work demonstrated the improvement of the therapeutic effects of DHA with AVA in CM, in comparison with DHA alone, and the active metabolite of the anti-malarial drug is recommended by the $\mathrm{WHO}$ as the first-line treatment for severe malaria. Moreover, the dosage of $3 \mathrm{mg} / \mathrm{kg}$ is between the maximal $(3.1 \mathrm{mg} / \mathrm{kg})$ and minimal $(1.6 \mathrm{mg} / \mathrm{kg})$ values recommended for use in patients with uncomplicated or severe malaria [32].

An advantage for the use of AVA as an adjuvant for anti-malarial drugs is that AVA is already largely recommended to decrease cardiac morbidity and mortality [33-36], with a dose and frequency higher than that used in this ECM protocol. These results confirmed not only the results of the first in vitro approach that was carried out with 13 isolates of Plasmodium falciparum [14], but also the therapeutic potential of the combination of DHA with AVA in vivo.

In this therapeutic scheme, the combination of DHA and AVA was administered, with five days of DHA and seven days of AVA, but the effect of DHA + AVA was not observed to be significant until D15. Our analysis of the biomarkers affected by this treatment revealed that Eotaxin/CCL11 and IL-13 were down-regulated and that MIP2 was up-regulated in the DHA + AVA group compared to the CT group at D6. MIP2 is known as a CXC chemokine that is implicated in the recruitment of immune cells [37,38], and eotaxin/CCL11 is a cytokine belonging to the $\mathrm{CC}$ chemokine family that selectively recruits eosinophils by inducing chemotaxis. The effects of CCL11 are mediated by its binding to a G-proteinlinked receptor known as a chemokine receptor, and it is able not only to decrease neurogenesis and cognitive performance [39] but also, with other chemokines, to induce the migration of circulating fibrocytes in patients with severe asthma [40]. IL-13 is one of the first mediators of inflammation and disease, which specifically induces the physiological changes in parasitized organs that are required to expel the offending organisms or their products. At D10, we observed an up-regulation of Eotaxin/CCL11 and LIX-CXCL5 and a down-regulation of MIP1 $\beta$-CCL4 in the DHA + AVA group, compared to the CT group. LIX-CXCL5 is known as a chemokine with angiogenic properties that stimulates the chemotaxis of neutrophils [41-43]. MIP1 $\beta$-CCL4 was also detected, and this finding is interesting because it has been demonstrated that a reduction of the T-cell-chemoattractant chemokines CCL3, CCL4 and CCL5 leads to cerebral malaria protection in mice [44], and like the other biomarkers cited above, MIP1 $\beta$-CCL4 plays a role in the chemotaxis of immune cells in during infection [45]. Taken together, these data support the hypothesis regarding the inhibition of the inflammatory process involved in $\mathrm{CM}$, and the combination of DHA + AVA can not only control parasitaemia but also alter the migration of immune cells. Moreover, AVA can block the post-translation modifications of G-proteins, indicating that it can inhibit chemokine receptors, which are also G-protein-linked receptors, that are involved in inflammatory and sepsis events.

The analyses of cytokine data agree with those from literature, but they also revealed some differences. In mice, it has been demonstrated that TNF, IFN $\gamma$, IL-1, IL-2, IL-6, IL-10, IL12, IL-18 [46-49] CXCL9 and IP10-CXCL10 are often detected in ECM [25,46-52]. Indeed, many studies were carried out to examine the chemokine and cytokine profiles related to ECM in mice, but this was carried out with various protocols (anti-malarial drugs injection and time after infection), and different outcomes were obtained. In the present model of $\mathrm{CM}$, the immune response was considered to be a sepsis-like response, prompting consideration of the biomarkers that could be detected in the blood. Moreover, the present analysis was conducted on serum and not on plasma or brain tissue [53,54]. Further experimentation should be carried out to confirm our hypothesis, such as examination of the biomarkers detected in the brain.

It is important to place this study in a clinical framework. $\mathrm{CM}$ presents two types of clinical challenges. The first is that cerebral pathogenesis can be observed quickly without any relationship between parasitaemia and clinical status [55,56], which requires prompt case management for patients. The second type of challenge is that neurologic impairments are observed among $25 \%$ of survivors $[57,58]$, including musculoskeletal disorder, cognitive trouble and other sequelae that may disturb life, the ability to work or, on a greater scale, the economy of a country.

Further studies should be conducted to resolve the solubility of AVA. In this protocol, AVA was i.p. injected. One of the crucial points among all statin-based experimentation for malaria is the development of a soluble form, which should be used for patients in critical status. The only water soluble statins are pravastatin and rosuvastatin [59].

The combination of DHA and AVA seemed to be effective as a therapeutic scheme in this survival study, and 
the delay of death in mice treated with this combination can be explained by the pleiotropic effects of statins on immune modulation, vascular inflammation, endothelial function and thrombogenesis. Although the capacity of statins to strongly modify cytokine and chemokine profiles is documented [17,49], only five biomarkers were identified as being associated with this survival modification. Further studies on this therapeutic treatment scheme are required to examine whether AVA is a suitable partner for current malaria drugs.

\section{Competing interests}

The authors have no conflicts of interest concerning the work reported in this paper.

\section{Authors' contributions}

$\mathrm{JD}$ and $\mathrm{CD}$ carried out the in vivo studies. JD, AP and CT carried out the immunoassays. JD, SB and BP conceived and coordinated the study. JD and SB analysed the data. JD, SB and BP drafted the manuscript. All authors read and approved the final manuscript.

\section{Acknowledgements}

The cerebral experiments in mice were designed by adapting the recommendations and protocols of Pr. Salah Mécheri, Associate Professor of the Biology of Host-Parasite Interactions Unit (Pasteur Institute, Paris, France), and Mr. Phillipe Grellier, Assistant Director at the National Museum of Natural History (Paris, France). Plasmodium berghei ANKA strains were kindly given by the Biology of Host-Parasite Interactions Unit.

This work was supported by the Délégation Générale pour l'Armement (grant no PDH-2-NRBC-4-B1-402).

\section{Author details}

${ }^{1}$ Unité de Parasitologie, Département d'Infectiologie de Terrain, Institut de Recherche Biomédicale des Armées, Marseille, France. ${ }^{2}$ Unité de Recherche sur les Maladies Infectieuses et Tropicales Emergentes, UM 63, CNRS 7278, IRD 198, Inserm 1095, Aix Marseille Université, Marseille, France. ${ }^{3}$ Direction Interarmées du Service de Santé, Cayenne, Guyane, France. ${ }^{4}$ Laboratoire de Parasitologie, Institut Pasteur de la Guyane, Cayenne, Guyane, France. ${ }^{5}$ UMR MD3, Institut de Recherche Biomédicale des Armées, Marseille, France.

Received: 8 April 2013 Accepted: 20 August 2013

Published: 30 August 2013

\section{References}

1. Dondorp A, Nosten F, Stepniewska K, Day N, White N: Artesunate versus quinine for treatment of severe falciparum malaria: a randomised trial. Lancet 2005, 366:717-725.

2. Dondorp AM, Fanello Cl, Hendriksen IC, Gomes E, Seni A, Chhaganlal KD, Bojang K, Olaosebikan R, Anunobi N, Maitland K, Kivaya E, Agbenyega T, Nguah SB, Evans J, Gesase S, Kahabuka C, Mtove G, Nadjm B, Deen J, Mwanga-Amumpaire J, Nansumba M, Karema C, Umulisa N, Uwimana A, Mokuolu OA, Adedoyin OT, Johnson WB, Tshefu AK, Onyamboko MA, Sakulthaew $T$ et al: Artesunate versus quinine in the treatment of severe falciparum malaria in African children (AQUAMAT): an open-label, randomised trial. Lancet 2010, 376:1647-1657

3. Amaratunga C, Sreng S, Suon S, Phelps ES, Stepniewska K, Lim P, Zhou C, Mao S, Anderson JM, Lindegardh N, Jiang H, Song J, Su XZ, White NJ, Dondorp AM, Anderson TJ, Fay MP, Mu J, Duong S, Fairhurst RM: Artemisinin-resistant Plasmodium falciparum in Pursat province, western Cambodia: a parasite clearance rate study. Lancet Infect Dis 2012, 12:851-858.

4. Dondorp AM, Nosten F, Yi P, Das D, Phyo AP, Tarning J, Lwin KM, Ariey F, Hanpithakpong W, Lee SJ, Ringwald P, Silamut K, Imwong M, Chotivanich K, Lim P, Herdman T, An SS, Yeung S, Singhasivanon P, Day NP, Lindegardh N, Socheat $D$, White $\mathrm{NJ}$ : Artemisinin resistance in Plasmodium falciparum malaria. N Engl J Med 2009, 361:455-467.
5. Noedl H, Se Y, Schaecher K, Smith BL, Socheat D, Fukuda MM: Evidence of artemisinin-resistant malaria in western Cambodia. N Engl J Med 2008, 359:2619-2620.

6. Rakotoarivelo RA, Razakarison C, Gottot S, Ravony Harintsoa L, Randrianiriana G, Andriamanjato D, Harilalarisoa H, Ramaniraka I, Rakotondramanga J, Rafaliarivony N, Ranaivoson F, Rakotonirina JF, Desplats D: Assessment of the management of cases of fever and malaria by general practitioners in the central Highlands of Madagascar, 2009-2010. Med Sante Trop 2012, 22:317-322

7. Haynes RK, Cheu KW, Chan HW, Wong HN, Li KY, Tang MM, Chen MJ, Guo ZF, Guo ZH, Sinniah K, Witte AB, Coghi P, Monti D: Interactions between artemisinins and other antimalarial drugs in relation to the cofactor model-A unifying proposal for drug action. Chem Med Chem 2012 7:2204-2226.

8. Pandey SK, Dwivedi H, Singh S, Siddiqui WA, Tripathi R: Antimalarial interaction of quinine and quinidine with clarithromycin. Parasitology 2012, 140:406-413.

9. White NJ: Preventing antimalarial drug resistance through combinations. Drug Resist Updat 1998, 1:3-9.

10. Pradines B, Torrentino-Madamet M, Fontaine A, Henry M, Baret E, Mosnier J, Briolant S, Fusai T, Rogier C: Atorvastatin is 10 -fold more active in vitro than other statins against Plasmodium falciparum. Antimicrob Agents Chemother 2007, 51:2654-2655.

11. Parquet $V$, Briolant $S$, Torrentino-Madamet M, Henry M, Almeras L, Amalvict $R$, Baret $E$, Fusai $T$, Rogier C, Pradines B: Atorvastatin is a promising partner for antimalarial drugs in treatment of Plasmodium falciparum malaria. Antimicrob Agents Chemother 2009, 53:2248-2252.

12. Wurtz N, Briolant S, Gil M, Parquet V, Henry M, Baret E, Amalvict R, Almeras $L$, Rogier C, Pradines B: Synergy of mefloquine activity with atorvastatin, but not chloroquine and monodesethylamodiaquine, and association with the pfmdr1 gene. J Antimicrob Chemother 2010, 65:1387-1394.

13. Parquet V, Henry M, Wurtz N, Dormoi J, Briolant S, Gil M, Baret E, Amalvict R, Rogier C, Pradines B: Atorvastatin as a potential anti-malarial drug: in vitro synergy in combinational therapy with quinine against Plasmodium falciparum. Malar J 2010, 9:139.

14. Savini H, Souraud JB, Briolant S, Baret E, Amalvict R, Rogier C, Pradines B: Atorvastatin as a potential antimalarial drug: in vitro synergy in combinational therapy with dihydroartemisinin. Antimicrob Agents Chemother 2010, 54:966-967.

15. Borek-Dohalsky V, Huclova J, Barrett B, Nemec B, Ulc I, Jelinek I: Validated HPLC-MS-MS method for simultaneous determination of atorvastatin and 2-hydroxyatorvastatin in human plasma-pharmacokinetic study. Anal Bioanal Chem 2006, 386:275-285.

16. Bienvenu AL, Picot S: Statins alone are ineffective in cerebral malaria but potentiate artesunate. Antimicrob Agents Chemother 2008, 52:4203-4204.

17. Souraud JB, Briolant S, Dormoi J, Mosnier J, Savini H, Baret E, Amalvict R, Soulard R, Rogier C, Pradines B: Atorvastatin treatment is effective when used in combination with mefloquine in an experimental cerebral malaria murine model. Malar J 2012, 11:13.

18. Lou J, Lucas R, Grau GE: Pathogenesis of cerebral malaria: recent experimental data and possible applications for humans. Clin Microbiol Rev 2001, 14:810-820. table of contents.

19. Delahaye NF, Coltel N, Puthier D, Barbier M, Benech P, Joly F, Iraqi FA, Grau GE, Nguyen C, Rihet P: Gene expression analysis reveals early changes in several molecular pathways in cerebral malaria-susceptible mice versus cerebral malaria-resistant mice. BMC Genomics 2007, 8:452.

20. Lackner P, Beer R, Heussler V, Goebel G, Rudzki D, Helbok R, Tannich E, Schmutzhard E: Behavioural and histopathological alterations in mice with cerebral malaria. Neuropathol App/ Neurobiol 2006, 32:177-188.

21. Kobbe R, Schreiber N, May J, Jacobs T: Simvastatin treatment shows no effect on the incidence of cerebral malaria or parasitemia during experimental malaria. Antimicrob Agents Chemother 2008, 52:1583-1584.

22. Helmers AJ, Gowda DC, Kain KC, Liles WC: Statins fail to improve outcome in experimental cerebral malaria and potentiate Toll-like receptormediated cytokine production by murine macrophages. Am J Trop Med Hyg 2009, 81:631-637.

23. Lackner P, Beer R, Helbok R, Broessner G, Engelhardt K, Brenneis C, Schmutzhard E, Pfaller K: Scanning electron microscopy of the neuropathology of murine cerebral malaria. Malar J 2006, 5:116.

24. White VA, Lewallen S, Beare NA, Molyneux ME, Taylor TE: Retinal pathology of pediatric cerebral malaria in Malawi. PLoS One 2009, 4:e4317. 
25. Reis PA, Estato V, da Silva TI, D'Avila JC, Siqueira LD, Assis EF, Bozza PT, Bozza FA, Tibiriça EV, Zimmerman GA, Castro-Faria-Neto HC: Statins decrease neuroinflammation and prevent cognitive impairment after cerebral malaria. PLoS Pathog 2012, 8:e1003099.

26. Martins YC, Carvalho LJ, Daniel-Ribeiro $C T$ : Challenges in the determination of early predictors of cerebral malaria: lessons from the human disease and the experimental murine models. Neuroimmunomodulation 2009, 16:134-145.

27. Hunt NH, Grau GE: Cytokines: accelerators and brakes in the pathogenesis of cerebral malaria. Trends Immunol 2003, 24:491-499.

28. Carvalho $L$, Lenzi HL, Pelajo-Machado M, Oliveira DN, Daniel-Ribeiro CT, Ferreira-da-Cruz MF: Plasmodium berghei: cerebral malaria in CBA mice is not clearly related to plasma TNF levels or intensity of histopathological changes. Exp Parasitol 2000, 95:1-7.

29. Taoufiq Z, Pino P, N'Dilimabaka N, Arrouss I, Assi S, Soubrier F, Rebollo A, Mazier D: Atorvastatin prevents Plasmodium falciparum cytoadherence and endothelial damage. Malar J 2011, 10:52

30. Greenwood J, Steinman L, Zamvil SS: Statin therapy and autoimmune disease: from protein prenylation to immunomodulation. Nat Rev Immunol 2006, 6:358-370.

31. Greenwood J, Mason JC: Statins and the vascular endothelial inflammatory response. Trends Immunol 2007, 28:88-98.

32. Newton PN, Barnes KI, Smith PJ, Evans AC, Chierakul W, Ruangveerayuth R, White NJ: The pharmacokinetics of intravenous artesunate in adults with severe falciparum malaria. Eur J Clin Pharmacol 2006, 62:1003-1009.

33. Arai H, Hiro T, Kimura T, Morimoto T, Miyauchi K, Nakagawa Y, Yamagishi M, Ozaki Y, Kimura K, Saito S, Yamaguchi T, Daida H, Matsuzaki M: More intensive lipid lowering is associated with regression of coronary atherosclerosis in diabetic patients with acute coronary syndrome. J Atheroscler Thromb 2010, 17:1096-1107.

34. Clauss SB, Holmes KW, Hopkins P, Stein E, Cho M, Tate A, Johnson-Levonas $A O$, Kwiterovich PO: Efficacy and safety of lovastatin therapy in adolescent girls with heterozygous familial hypercholesterolemia. Pediatrics 2005, 116:682-688.

35. Miura S, Saku K: Effects of statin and lipoprotein metabolism in heart failure. J Cardiol 2010, 55:287-290.

36. Versmissen J, Oosterveer DM, Yazdanpanah M, Defesche JC, Basart DC, Liem AH, Heeringa J, Witteman JC, Lansberg PJ, Kastelein JJ, Sijbrands EJ: Efficacy of statins in familial hypercholesterolaemia: a long term cohort study. BMJ 2008, 337:a2423.

37. Ohtsuka Y, Lee J, Stamm DS, Sanderson IR: MIP-2 secreted by epithelial cells increases neutrophil and lymphocyte recruitment in the mouse intestine. Gut 2001, 49:526-533.

38. Yan XT, Tumpey TM, Kunkel SL, Oakes JE, Lausch RN: Role of MIP-2 in neutrophil migration and tissue injury in the herpes simplex virus-1infected cornea. Invest Ophthalmol Vis Sci 1998, 39:1854-1862.

39. Villeda SA, Luo J, Mosher Kl, Zou B, Britschgi M, Bieri G, Stan TM, Fainberg N, Ding Z, Eggel A, Lucin KM, Czirr E, Park JS, Couillard-Despres S, Aigner L, L G, Peskind ER, Kaye JA, Quinn JF, Galasko DR, Xie XS, Rando TA, Wyss-Coray $T$ : The ageing systemic milieu negatively regulates neurogenesis and cognitive function. Nature 2011, 477:90-94.

40. Isgro M, Bianchetti L, Marini MA, Bellini A, Schmidt M, Mattoli S: The C-C motif chemokine ligands CCL5, CCL11, and CCL24 induce the migration of circulating fibrocytes from patients with severe asthma. Mucosal Immunol 2013, 6:718-724.

41. Mei J, Liu Y, Dai N, Hoffmann C, Hudock KM, Zhang P, Guttentag SH, Kolls JK, Oliver PM, Bushman FD, Worthen GS: Cxcr2 and Cxcl5 regulate the IL-17/G CSF axis and neutrophil homeostasis in mice. J Clin Invest 2012, 122:974-986.

42. Song J, Wu C, Zhang X, Sorokin LM: In vivo processing of CXCL5 (LIX) by matrix metalloproteinase (MMP)-2 and MMP-9 promotes early neutrophil recruitment in IL-1beta-induced peritonitis. J Immunol 2013, 190:401-410.

43. Zhou SL, Dai Z, Zhou ZJ, Wang XY, Yang GH, Wang Z, Huang XW, Fan J, Zhou J: Overexpression of CXCL5 mediates neutrophil infiltration and indicates poor prognosis for hepatocellular carcinoma. Hepatology 2012 $56: 2242-2254$

44. Clark CJ, Phillips RS: Cerebral malaria protection in mice by speciesspecific Plasmodium coinfection is associated with reduced CC chemokine levels in the brain. Parasite Immunol 2011, 33:637-641.

45. Steigerwald M, Moll H: Leishmania major modulates chemokine and chemokine receptor expression by dendritic cells and affects their migratory capacity. Infect Immun 2005, 73:2564-2567.
46. Basir R, Rahiman SF, Hasballah K, Chong W, Talib H, Yam M, Jabbarzare M, Tie T, Othman F, Moklas M, Abdullah W, Ahmad Z: Plasmodium berghei ANKA infection in ICR mice as a model of cerebral malaria. Iran J Parasitol 2012, 7:62-74

47. Villegas-Mendez A, Greig R, Shaw TN, de Souza JB, Gwyer Findlay E, Stumhofer JS, Hafalla JC, Blount DG, Hunter CA, Riley EM, Couper KN: IFNgamma-producing CD4+ T cells promote experimental cerebral malaria by modulating CD8+ T cell accumulation within the brain. $J$ Immunol 2012, 189:968-979.

48. Niessner A, Steiner S, Speidl WS, Pleiner J, Seidinger D, Maurer G, Goronzy JJ, Weyand CM, Kopp CW, Huber K, Wolzt M, Wojta J: Simvastatin suppresses endotoxin-induced upregulation of toll-like receptors 4 and 2 in vivo. Atherosclerosis 2006, 189:408-413.

49. Terblanche M, Almog Y, Rosenson RS, Smith TS, Hackam DG: Statins and sepsis: multiple modifications at multiple levels. Lancet Infect Dis 2007, 7:358-368

50. Wilson NO, Jain $V$, Roberts CE, Lucchi N, Joel PK, Singh MP, Nagpal AC, Dash AP, Udhayakumar V, Singh N, Stiles JK: CXCL4 and CXCL10 predict risk of fatal cerebral malaria. Dis Markers 2011, 30:39-49.

51. Sarfo BY, Wilson NO, Bond VC, Stiles JK: Plasmodium berghei ANKA infection increases Foxp3, IL-10 and IL-2 in CXCL-10 deficient C57BL/6 mice. Malar J 2011, 10:69.

52. Fauconnier M, Palomo J, Bourigault ML, Meme S, Szeremeta F, Beloeil JC, Danneels A, Charron S, Rihet P, Ryffel B, Quesniaux VF: IL-12Rbeta2 is essential for the development of experimental cerebral malaria. J Immunol 2012, 188:1905-1914.

53. Kurtzhals JA, Adabayeri V, Goka BQ, Akanmori BD, Oliver-Commey JO, Nkrumah FK, Behr C, Hviid L: Low plasma concentrations of interleukin 10 in severe malarial anaemia compared with cerebral and uncomplicated malaria. Lancet 1998, 351:1768-1772.

54. Hanum PS, Hayano M, Kojima S: Cytokine and chemokine responses in a cerebral malaria-susceptible or -resistant strain of mice to Plasmodium berghei ANKA infection: early chemokine expression in the brain. Int Immunol 2003, 15:633-640.

55. Martins YC, Werneck GL, Carvalho $\sqcup$, Silva BP, Andrade BG, Souza TM, Souza DO, Daniel-Ribeiro CT: Algorithms to predict cerebral malaria in murine models using the SHIRPA protocol. Malar J 2010, 9:85.

56. Trampuz A, Jereb M, Muzlovic I, Prabhu RM: Clinical review: severe malaria. Crit Care 2003, 7:315-323

57. Carter JA, Mung'ala-Odera V, Neville BG, Murira G, Mturi N, Musumba C, Newton CR: Persistent neurocognitive impairments associated with severe falciparum malaria in Kenyan children. J Neurol Neurosurg Psychiatry 2005, 76:476-481

58. Boivin MJ, Bangirana P, Byarugaba J, Opoka RO, Idro R, Jurek AM, John CC Cognitive impairment after cerebral malaria in children: a prospective study. Pediatrics 2007, 119:e360-e366.

59. Water and lipid soluble statins: [https://www.gpnotebook.co.uk/simplepage. cfm?lD=x20120104193906598025]

doi:10.1186/1475-2875-12-302

Cite this article as: Dormoi et al:: Improvement of the efficacy of dihydroartemisinin with atorvastatin in an experimental cerebral malaria murine model. Malaria Journal 2013 12:302.

\section{Submit your next manuscript to BioMed Central and take full advantage of:}

- Convenient online submission

- Thorough peer review

- No space constraints or color figure charges

- Immediate publication on acceptance

- Inclusion in PubMed, CAS, Scopus and Google Scholar

- Research which is freely available for redistribution 